\title{
Значимість окремих маркерів при різних варіантах перебігу раку передміхурової залози
}

\author{
${ }^{1}$ Національний інститут раку, Київ \\ ${ }^{2}$ Інститут експериментальної патологї̈, онкології та радіобіології ім. Р.С. Кавецького НАН України, Київ \\ ${ }^{3}$ Донецький національний медичний університет, Лиман \\ Одержано: 14.08 .2020 \\ Прийнято до друку: 1.09.2020
}

DOI: 10.32471/clinicaloncology.2663-466X.39-3.27338

Актуальність. У структурі онкологічної патології у чоловіків рак передміхурової залози (РПЗ) посідає 1-ше місце, при цьому $\epsilon 2$-ю за частотою причиною смерті від злоякісних новоутворень, а 5-річний показник виживаності становить $30 \%$. Простатичний специфічний антиген належить до основних пухлиноасоційованих маркерів, а при певних варіантах перебігу РПз діагностична і прогностична значущість інших маркерів залишається мало вивченою, хоча між окремими показниками аналізу крові існують високовірогідні кореляційні зв'язки. Мета дослідження. Оцінити клініко-прогностичну значущість окремих пухлинних маркерів у крові хворих на РПЗ. Об'єкт і методи дослідження. Під спостереженням знаходилися 195 чоловіків з РПЗ віком 52-82 років. 3 моменту діагностування захворювання минуло в середньому 3 роки. Співвідношення

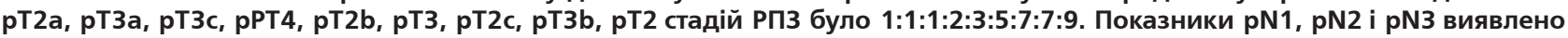
у 22, 9 і 8\% обстежених відповідно, рM1 і рM2 - у 26 і 17\% відповідно. Параметри поширеності раку в середньому становили 3 бали, розміру пухлини - 2 бали, критерію Глісона - 6 балів, співвідношення периферичної та центральної форми пухлини - 3:1, аденокарциному діагностовано в 94\% пацієнтів, гігантоклітинну карциному - у $6 \%$. Середній показник стадії пухлини становив 3 умовні одиниці, зрілості - 3 бали. Оцінювали показники тестостерону, лютеїнізуючого гормону, інсуліноподібного фактору росту 1, активності лужної фосфатази, кислої простатичної фосфатази і глікозил-гідролази. Результати. Підвищення рівнів простатичного специфічного антигену, тестостерону, інсуліноподібного фактору росту 1 , активності лужної фосфатази, кислої простатичної фосфатази і козилгідролази спостерігається у 46-100\% хворих, що залежить від поширеності, розмірів, локалізації, стадії й ступеня диференціації пухлинного процесу, характеру його метастазування в лімфатичні вузли, віддалені органи та скелет, а параметри активності лужної фосфатази і кислої простатичної фосфатази мають прогностичне значення. 3 урахуванням виконаної статистичної обробки даних обстеження зроблено висновок, що має практичну спрямованість: показник активності кислої простатичної фосфатази > 7,5 нг/мл має негативне прогностичне значення щодо метастазів у печінку. Таким чином, необхідна розробка нових алгоритмів, що поліпшують доопераційну оцінку стадій РПЗ. Висновок. Підвищення рівня маркерів РПЗ, що вивчалися, залежить від характеру перебігу пухлинного процесу, а деякі параметри мають прогностичне значення.

Ключові слова: рак; передміхурова залоза; пухлинні маркери.

\section{ВСТУП}

У структурі онкологічної патології у чоловіків рак передміхурової залози (РПЗ) посідає провідні позиції [1, 2], при цьому $€$ другою за частотою причиною смерті від злоякісних новоутворень [3, 4]. Захворюваність та смертність внаслідок РПЗ в усьому світі шорічно підвишуються $[5,6]$.

До основних пухлиноасоційованих маркерів належить простатичний специфічний антиген (prostate-specific antigen PSA) [7], а при певних варіантах перебігу РПЗ діагностична й прогностична значущість відводиться показникам тестостерону (testosterone - TS) [8], лютеїнізуючого гонадотропного гормону (luteinizing hormone - LH) [9], інсуліноподібного фактора росту 1 (insulin-like growth factor 1 - IGF1) [10], активності простатичної кислої фосфатази (acid prostatic phosphatase - APP) [11] і лужної фосфатази (acid phosphatase AP) [12]. Між показниками окремих біомаркерів у крові хворих на РПЗ існують тісні кореляційні зв'язки, але їх клінічна й прогностична значимість залишається вивченою недостатньо [13].

\section{МЕТА ДОСЛІДЖЕННЯ}

Метою дослідження є оцінка клініко-прогностичної значимості окремих пухлинних маркерів у крові хворих на РПЗ.

\section{ОБ 'ЄКТ І МЕТОДИ ДОСЛІДЖЕННЯ}

Хворі перебували на обстеженні та лікуванні в Національному інституті раку (Київ). У дослідження увійшли пацієнти, яким виконано простатектомію, але обстеження здійснено до оперативного втручання. Критеріями виключення були хворі зі стадією патологічного процесу нижче II. Під спосте- реженням знаходилися 195 чоловіків з РПЗ віком 52-82 років (у середньому $66,3 \pm 6,89$ року). 3 моменту діагностування захворювання минуло від 5 міс до 17 років (у середньому $3,2 \pm 0,19$ року). Співвідношення рT2a, pT3a, pT3c, pT4, pT2b, pT3, pТ2c, pТ3b, рТ2 стадій РП3 становило 1:1:1:2:3:5:7:7:9. Показники pN1, pN2 і pN3 виявлено у 22, 9 і 8 обстежених відповідно, рМ1 і рМ2 - відповідно у 26 і 17\%. Параметри поширеності раку становили $3,2 \pm 0,12$ бала, розміру пухлини $1,9 \pm 0,06$ бала, значення критерію Глісона $-6,4 \pm 0,08$ бала. Співвідношення периферійної та центральної форм РПЗ становило $3: 1$, локалізацію пухлини в задньому відділі передміхурової залози встановлено у $56,9 \%$ випадків, у бічних - у $36,9 \%$, у передньому - у 6,2\%. Аденокарциному діагностовано у $93,9 \%$ обстежених хворих, гігантоклітинну карциному - у 6,2\%. Метастази в лімфатичних вузлах виявлено у $38,5 \%$ пацієнтів, у віддалених органах - у $18,6 \%$, у скелеті - у $28,0 \%$.

Діагностування РПЗ і його метастазів базувалося на клінічних, лабораторних, променевих (рентгенологічних, комп'ютерних томографічних, сонографічних), фіброскопічних, цитологічних (гістологічних) методах дослідження. Використовували апарати «Multix-Compact-Siemens» (Німеччина), «Somazom-Emotion-6-Siemens» (Німеччина), «GygoscanIntera-Philips» (Нідерланди), «Envisor-Philips» (Нідерланди). Рівні в сироватці крові PSA, TS і LH вивчали методом імунохімічного аналізу з використанням аналізатора «Cobas-6000» та тест-системи «Roche-Diagnostics» (Швейцарія), активність APP і вміст IGF (соматомедіну C) - методом імуноферментного аналізу (рідер «PR2100-Sanofi diagnostic pasteur», Франція) із тест-системою «Immulite-Siemens-AG» (Німеччина), 
активність глікозил-гідролази (glycoside hydrolases - GH) й AP - за допомогою біохімічного аналізатора «OlympusAU640» (Японія).

Оцінювали критерій Глісона, ступінь диференціації РПЗ (GDT) і його стадію (STT), підраховували інтегральний індекс тяжкості пухлинного процесу (IWT) за формулою:

$$
\mathrm{IWT}=\frac{(T+2 N+3 M) \cdot G S}{I},
$$

де $T$ - міжнародний показник характеру первинної пухлини, $N$ - міжнародний показник груп метастатичного ураження регіональних лімфатичних вузлів, $M$ - сума груп метастазів у віддалених органах, $G S$ - критерій Глісона, $I-$ тривалість захворювання. Показник STT становив $3,0 \pm 0,07$ умовної одиниці, GDT $-2,5 \pm 0,05$ бала, IWT $-17,2 \pm 1,18$ в.о. У якості контролю обстежено 30 практично здорових чоловіків віком $50-73$ років (у середньому $64,7 \pm 2,52$ року).

Статистичну обробку отриманих результатів досліджень проведено за допомогою комп'ютерного варіаційного, непараметричного, кореляційного, одно- (ANOVA) і багатофакторного (ANOVA/MANOVA) дисперсійного аналізу (програми Microsoft Excel та Statistica StatSoft, США). Оцінювали середні значення (М), їх стандартні похибки (standard error - SE) й відхилення (standard deviation - SD), критерії параметричної кореляції Пірсона (r), непараметричної кореляції Кендалла (t), однофакторного дисперсійного аналізу (D), однорідності дисперсії Брауна - Форсайта (Brown - Forsythe - BF) та Уїкоксона - Pao (Wilcoxon - Rao - WR), відмінностей Стьюдента (t), а також достовірність статистичних показників (p). Підраховували ступінь прогнозування результату (PPV). У даному дослідженні критичний рівень значущості при перевірці статистичних гіпотез вважали рівним 0,05 .

\section{РЕЗУЛЬТАТИ}

Вихідні показники онкоасоційованих маркерів у сироватці крові здорових чоловіків контрольної групи та хворих на РПЗ подано в табл. 1. У порівнянні з групою контролю встановлено підвищення показників PSA в 16,1 раза, TS - на $18 \%$, IGF на $69 \%$, АРP - в 2,7 раза, AP - в 2,1 раза і $\mathrm{GH}-$ на $60 \%$, а зміни цих параметрів (>M+SD здорових осіб) виявлено відповідно у $100 ; 46,2 ; 65,1 ; 99,5 ; 99,0$ і 76,4\% обстежених пацієнтів (рис. 1-2).

За результатами багатофакторного дисперсійного аналізу Уїлкоксона - Рао (рис. 3), на інтегральний стан маркерів пухлинного процесу при РПЗ впливають $(\mathrm{p}<0,001)$ показники pT $(\mathrm{WR}=2,35), \mathrm{pN}(\mathrm{WR}=3,30), \mathrm{pM}(\mathrm{WR}=4,95)$, поширеність й розмір пухлини (відповідно $\mathrm{WR}=2,35 \mathrm{i} \mathrm{WR}=4,22)$, критерій Глісона (WR $=1,92)$, центральна форма раку $(\mathrm{WR}=3,13), \mathrm{STT}$ $(\mathrm{WR}=3,50)$, GDT $(\mathrm{WR}=1,75)$, розвиток метастазів у лімфатичних вузлах $(\mathrm{WR}=2,38)$, віддалених органах $(\mathrm{WR}=2,33)$ і скелеті $(\mathrm{WR}=2,42)$.

Таблиця 1. Показники маркерів РПЗ у крові здорових осіб контрольної групи і обстежених хворих (M $\pm \mathrm{SD} \pm \mathrm{SE})$

\begin{tabular}{lcccc}
\hline \multirow{2}{*}{ Показник } & \multicolumn{2}{c}{ Група обстежених } & \multicolumn{2}{c}{ Відмінності } \\
\cline { 2 - 6 } & 3дорові (n=30) & Хворі (n=195) & $\mathbf{t}$ & $\mathbf{p}$ \\
\hline $\mathrm{PSA}$, нг/мл & $2,0 \pm 0,92 \pm 0,17$ & $32,1 \pm 16,63 \pm 1,19$ & 9,87 & $<0,001$ \\
TS, нмоль/л & $15,9 \pm 4,58 \pm 0,84$ & $18,7 \pm 6,57 \pm 0,47$ & 2,32 & 0,021 \\
LH, мО/мл & $5,1 \pm 1,42 \pm 0,26$ & $4,9 \pm 2,34 \pm 0,17$ & 0,48 & 0,631 \\
IGF, нг/мл & $137,7 \pm 66,40 \pm 12,12$ & $232,2 \pm 76,66 \pm 5,49$ & 6,39 & $<0,001$ \\
APP, нг/мл & $2,1 \pm 0,67 \pm 0,12$ & $5,7 \pm 1,80 \pm 0,13$ & 10,72 & $<0,001$ \\
AP, О/л & $79,0 \pm 33,67 \pm 6,15$ & $164,5 \pm 22,03 \pm 1,58$ & 18,28 & $<0,001$ \\
GH, O/л & $93,7 \pm 39,12 \pm 7,14$ & $149,8 \pm 39,58 \pm 2,84$ & 7,23 & $<0,001$ \\
\hline
\end{tabular}

\section{ОБГОВОРЕННЯ}

Вибір універсальних прогностичних маркерів РПЗ при різних стадіях захворювання викликає чималі труднощі [14]. PSA належить до основних пухлиноасоційованих маркерів, що мають прогностичне значення [7], хоча це частково відноситься також до АРP $[15,16]$ і АР [17]. Ми відібрали ті показники маркерів пухлинного процесу, які одночасно мали вірогідні дисперсійні зв'язки Брауна - Форсайта і кореляційні непараметричні Кендалла 3 параметрами перебігу РПЗ. Виявилося, що LH обернено співвідноситься 3 GDT $(B F=2,59, p=0,048 ; t=-0,269, p<0,001)$ і прямо з наявністю метастазів в клубових лімфатичних вузлах $(\mathrm{BF}=2,44$, $\mathrm{p}=0,047 ; \mathrm{t}=+0,115, \mathrm{p}=0,017)$, АРР має позитивні зв'язки з наявністю метастазів у мезентеріальних лімфатичних вузлах $(\mathrm{BF}=2,22, \mathrm{p}=0,043 ; \mathrm{t}=+0,093, \mathrm{p}=0,046)$ і печінці $(\mathrm{BF}=2,45$, $\mathrm{p}=0,048 ; \mathrm{t}=+0,101, \mathrm{p}=0,038), \mathrm{PSA}-3$ проростанням пухлини в сечовий міхур $(B F=6,56, p=0,011 ; t=+0,110, p=0,022)$, $\mathrm{TS}-3$ критерієм Глісона $(\mathrm{BF}=4,45, \mathrm{p}=0,036 ; \mathrm{t}=+0,183$, $\mathrm{p}=0,046), \mathrm{AP}-3$ метастазами в хребет $(\mathrm{BF}=2,02, \mathrm{p}=0,029$; $\mathrm{t}=+0,143, \mathrm{p}=0,003)$.

Як відомо, РПЗ належить до пухлин, що найбільш часто метастазують у кістки, що, за даними літератури, сягає $70 \%$ випадків [15]. Біохімічним показником діагностики метастазів у кістково-суглобовий апарат хворих на РПЗ є рівень

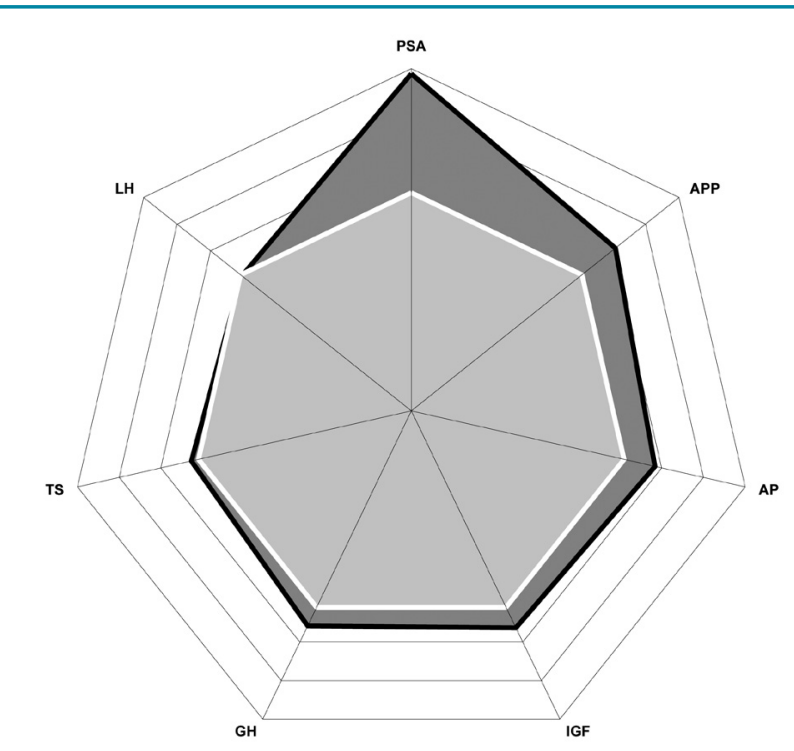

Рис. 1. Відмінності показників маркерів РПЗ у хворих у порівнянні з аналогічними у здорових осіб, яких прийнято за $100 \%(\ln , \%)$

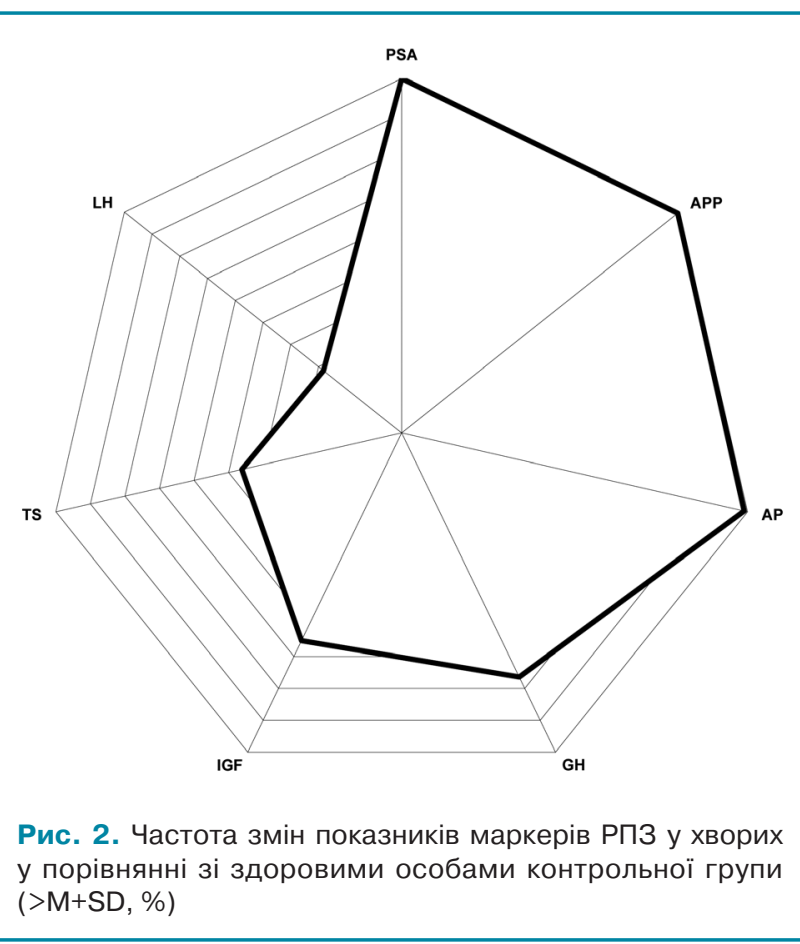




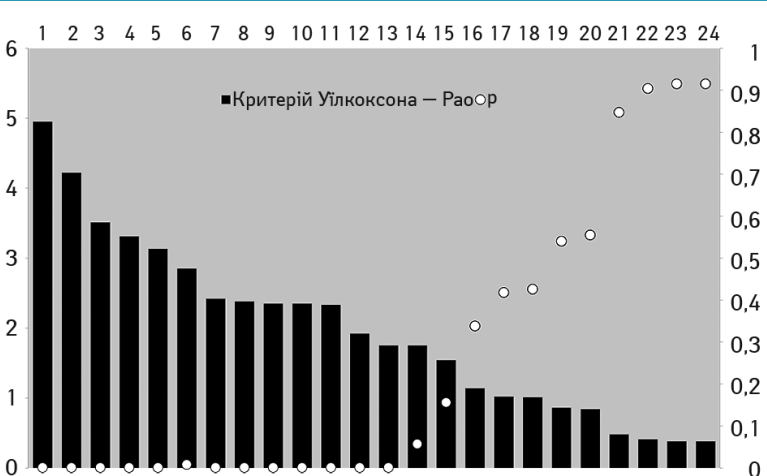

Рис. 3. Ступінь впливу окремих чинників перебігу РПЗ на інтегральні параметри маркерів пухлинного процесу: 1 - показник рM; 2 - розмір пухлини; 3 - показник STT; 4 - показник рN; 5 - центральна форма РП3; 6 - наявність макрогематурії; 7 - наявність метастазів у скелеті; 8 - наявність метастазів у лімфатичних вузлах; $9-$ показник рT; 10 - поширеність пухлинного процесу; 11 - наявність метастазів у віддалених органах; 12 - показник критерію Глісона; 13 - показник GDT; 14 - локалізація пухлини в передньому відділі залози; 15 - наявність гідронефрозу; 16 - периферична форма РПЗ; 17 - наявність висхідного обструктивного пієлонефриту; 18 - наявність проростання пухлини в сечовий міхур; 19 - локалізація пухлини в задній частці залози; 20 - наявність проростання пухлини в пряму кишку; 21 - локалізація пухлини в бічних відділах залози; 22 - гігантоклітинна карцинома передміхурової залози; 23 показник IWT; 24 - аденокарцинома передміхурової залози

Таблиця 2. Характер кореляційних зв'язків Пірсона показників маркерів РПЗ з параметрами перебігу захворювання

\begin{tabular}{lcccccc}
\hline Показник & \multicolumn{6}{c}{ Параметр перебігу PП3 } \\
\cline { 2 - 7 } \multicolumn{1}{c}{ маркерів } & \multicolumn{2}{c}{ STT } & \multicolumn{3}{c}{ GDT } & \multicolumn{2}{c}{ IWT } \\
\cline { 2 - 7 } \multicolumn{1}{c}{$\mathbf{~}$} & $\mathbf{r}$ & $\mathbf{p}$ & $\mathbf{r}$ & $\mathbf{p}$ & $\mathbf{r}$ & $\mathbf{p}$ \\
\hline PSA & $+0,072$ & 0,315 & $-0,444$ & $<0,001$ & $+0,205$ & 0,004 \\
TS & $+0,086$ & 0,231 & $+0,060$ & 0,405 & $+0,064$ & 0,374 \\
LH & $+0,078$ & 0,276 & $+0,001$ & 0,990 & $-0,031$ & 0,663 \\
IST & $+0,052$ & 0,468 & $-0,002$ & 0,977 & $+0,045$ & 0,532 \\
APP & $+0,119$ & 0,096 & $-0,094$ & 0,192 & $+0,035$ & 0,623 \\
AP & $+0,375$ & $<0,001$ & $-0,022$ & 0,763 & $+0,091$ & 0,206 \\
GH & $+0,214$ & 0,003 & $+0,116$ & 0,108 & $+0,334$ & $<0,001$ \\
\hline
\end{tabular}

активності в сироватці крові АР $[18,19]$. Нами у хворих з метастазами в хребет встановлено вірогідно вищі (на 13\%) показники активності АР $(178,0 \pm 2,12$ О/л і 157,2 $\pm 1,85$ O/л; $\mathrm{t}=3,87$, $\mathrm{p}<0,001)$, а з метастазами в печінку - на $36 \%$ вищу активність

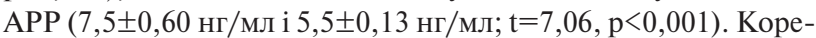
ляційний аналіз Пірсона (табл. 2) демонструє прямі зв'язки STT 3 AP i GH, a IWT - 3 PSA та GH.

3 урахуванням виконаної статистичної обробки даних обстеження зроблено висновок, що має практичну спрямованість: показник активності APP $>7,5$ нг/мл ( $>\mathrm{M}+\mathrm{SD}$ хворих на РПЗ) свідчить про негативний прогноз щодо метастазів у печінку (PPV=75,0\%), а АР >190 О/л - стосовно метастазів у хребет $(\mathrm{PPV}=87,1 \%)$.

\section{висновки}

1. Підвищення рівнів PSA, TS, IGF, AP, APP і GH спостерігається у 46-100\% хворих на РПЗ, що залежить від поширеності, розмірів, локалізації, стадії й ступеня диференціації пухлинного процесу, характеру його метастазування в лімфатичні вузли, віддалені органи та скелет.

2. Параметри активності АР і АРP мають прогностичне значення.

3. Показник активності АРP > 7,5 нг/мл свідчить про негативний прогноз щодо метастазів у печінку.

4. Враховуючи дані пухлинних маркерів, доцільною є розробка нових алгоритмів діагностики, що поліпшуватимуть доопераційну оцінку стадій РПЗ, вибір технології променевої й хіміотерапії, а також визначення параметрів, які дозволятимуть прогнозувати перебіг захворювання й контролювати ефективність лікувальних заходів.

\section{ЕТИЧНІ ПОЛОЖЕННЯ}

Робота виконувалася відповідно до етичних стандартів, викладених у Гельсінській декларації Всесвітньої медичної асоціації, і пацієнти дали свою інформовану згоду на дослідження, схвалене Комісією з біоетики Національного інституту раку (Київ).

\section{КОНФЛІКТ ІНТЕРЕСІВ}

Автори заявляють про відсутність конфлікту інтересів. Автори не отримували від окремих осіб і організацій фінансової підтримки дослідження, гонорарів та інших форм винагород.

\section{СПИСОК ВИКОРИСТАНОЇ ЛІТЕРАТУРИ}

1. Gesmundo, I., Di Blasio, L., Banfi, D., Villanova, T., Fanciulli, A., Favaro, E., ... Granata, R. (2019). Proton pump inhibitors promote the growth of androgen-sensitive prostate cancer cells through ErbB2, ERK1/2, PI3K/Akt, Критерію Глісона K-3ß signaling and inhibition of cellular prostatic acid phosphatase. Cancer Letters, 449(1): 252-262. doi: 10.1016/j.canlet.2019.02.028.

2. Ouellette, V., Côté, M. F., Gaudreault, R. C., Tajmir-Riahi, H. A., \& Bérubé, G. (2019). Second-generation testosterone-platinum(II) hybrids for site-specific treatment of androgen receptor positive prostate cancer: Design, synthesis and antiproliferative activity. European Journal of Medicinal Chemistry, 29(179): 660-666. doi: 10.1016/j.ejmech.2019.06.090.

3. Cheaito, K. A., Bahmad, H. F., Hadadeh, O., Saleh, E., \& Dagher, C. (2019). emt markers in locally-advanced prostate cancer: predicting recurrence? Frontiers in Oncology, 11(9): 131. doi: 10.3389/fonc.2019.00131.

4. Lang, R., Rolny, V., Leinenbach, A., Karl, J., Swiatek-de Lange, M., Kobold, U., Vogeser, M. (2019). Investigation on core-fucosylated prostate-specific antigen as a refined biomarker for differentiation of benign prostate hyperplasia and prostate cancer of different aggressiveness. Tumour Biology, 41(3): 27223. doi: $10.1177 / 1010428319827223$

5. Xu, W., Qian, J., Zeng, F., Li, S., Guo, W., Chen, L., ... Deng, F. (2019). Protein kinase Ds promote tumor angiogenesis through mast cell recruitment and expression of angiogenic factors in prostate cancer microenvironment. Journal of Experimental \& Clinical Cancer Research, 38(1): 114-119. doi: 10.1186/s13046-019-1118-y.

6. Zhao, J. G., Nie, L., Chen, X. Q., Chen, N., \& Zeng, H. (2019). The subgroup analysis of the prognostic value of the intraductal carcinoma of the prostate in patients with metastatic prostate cancer. Zhonghua Wai Ke Za Zhi, 57(6): 422-427. doi: 10.3760/cma.j.issn.0529-5815.2019.06.006.

7. Hugosson, J., Roobol, M. J., Månsson, M., Tammela, T. L. J., Zappa, M., Nelen, V., ... Auvinen, A. (2019). A 16-yr follow-up of the european randomized study of screening for prostate cancer. European Urology, 26(2): 30150-30152. doi: 10.1016/j.eururo.2019.02.009

8. Morote, J., \& Comas, I. (2019). Serum testosterone level is a useful biomarker for determining the optimal treatment for castration-resistant prostate cancer. Urologic Oncology, 22(6): 30202-30209. doi: 10.1016/j.urolonc.2019.05.016.

9. Wang, W., Chen, Z. X., Guo, D. Y., \& Tao, Y. X. (2018). Regulation of prostate cancer by hormone-responsive $\mathrm{G}$ protein-coupled receptors. Pharmacology \& Therapeutics. 191(11): 135-147. doi: 10.1016/j.pharmthera.2018.06.005.

10. Pak, S., Park, S. Y., Shin, T. J., You, D., Jeong, I. G., Hong, J. H., ... Ahn, H. (2019). Association of muscle mass with survival after radical prostatectomy in patients with prostate cancer. The Journal of Urology, 202(3): 525-532. doi: 10.1097/JU.0000000000000249.

11. Fredj, Z., Ben Ali, M., Abbas, M. N., \& Dempsey, E. (2019). Determination of prostate cancer biomarker acid phosphatase at a copper phthalocyaninemodified screen printed gold transducer. Analytica Chimica Acta, 30(1057): 98-105. doi: 10.1016/j.aca.2018.12.058.

12. Kobayashi, T., Namitome, R., Hirata, Y. U., Shiota, M., Imada, K., Kashiwagi, E.,

Eto, M. (2020). Serum prognostic factors of androgen-deprivation therapy among japanese men with de novometastatic prostate cancer. Anticancer Research, 39(6): 3191-3195. doi: 10.21873/anticanres. 13457.

13. Bedolla, R. G., Shah, D. P., Huang, S. B., Reddick, R. L., Ghosh, R., \& Kumar, A.P. (2019). Receptor tyrosine kinase recepteur d'origine nantais as predictive marker for aggressive prostate cancer in African Americans. Molecular Carcinogenesis, 11(3), 854-861. doi: $10.1002 /$ mc.23002.

14. Dmitriev, A. A., Rosenberg, E. E., Krasnov, G. S., Gerashchenko, G. V., Gordiyuk, V.V., ... Kashuba, V.I. (2015). Identification of novel pigenetic markers of prostate cancer by notl-microarray analysis. Disease Markers, 2015, 241301. doi: $10.1155 / 2015 / 241301$.

15. Quiroz-Munoz, M., Izadmehr, S., Arumugam, D., Wong, B., Kirschenbaum, A., \& Levine, A. C. (2019). Mechanisms of osteoblastic bone metastasis in prostate cancer: role of prostatic acid phosphatase. Journal of the Endocrine Society, 3(3): 655-664. doi: $10.1210 /$ js.2018-00425.

16. Xu, H., Wang, F., Li, H., Ji, J., Cao, Z., ... Sun, Y. (2019). Prostatic acid phosphatase (PAP) predicts prostate cancer progress in a population-based study: The renewal of PAP? Disease Markers, 23(1): 7090545. doi: 10.1155/2019/7090545.

17. Ranasinghe, L., Cotogno, P., Ledet, E., Bordlee, B., Degeyter, K., Nguyen, N., ... Sartor, AO. (2019). Relationship between serum markers and volume of liver metastases in castration-resistant prostate cancer. Cancer Treatment and Research Communications, 20(1): 100151. doi: 10.1016/j.ctarc.2019.100151.

18. Shepherd, K. L., Cool, P., \& Cribb, G. (2018). Prognostic indicators of outcome for patients with skeletal metastases from carcinoma of the prostate. The Bone \& Joint Journal, 100(12): 1647-1654. doi: 10.1302/0301-620X.100B12.BJJ-2018-0697.

19. Armstrong, A. J., Gupta, S., Healy, P., Kemeny, G., Leith, B., Zalutsky, M. R., ... George, D. J. (2019). Pharmacodynamic study of radium-223 in men with bone metastatic castration resistant prostatecancer. PLoS One, 14(5): 0216934. doi: 10.1371/journal.pone.0216934. 
Значимость отдельных маркеров при различных вариантах течения рака предстательной железы

О.Ю. Столярова ${ }^{1}$ Ю.В. Думанский ${ }^{2}$, М.И. Палий ${ }^{1}$

О.В. Синяченко

Национальный институт рака, Киев ${ }^{2}$ Институт экспериментальной патологии, онкологии и радиобиологии им. P.Е. Кавецкого НАН Украины, Киев ${ }^{3}$ Донецкий национальный медицинский университет, Лиман

Резюме. Актуальность. В структуре онкологической патологии у мужчин рак предстательной железы (РПЖ) занимает 1-е место, при этом является 2-й по частоте причиной смерти вследствие злокачественных новообразований, a 5-летний показатель выживаемости составляет 30\%. Простатический специфический антиген относится к основным опухолеассоциированным маркерам, а при определенных вариантах течения РПЖ диагностическая и прогностическая значимость других маркеров остается малоизученной, хотя между отдельными показателями анализа крови существуют с высокой вероятностью достоверно корреляционные связи. Цель исследования. Оценить клинико-прогностическую значимость отдельных опухолевых маркеров в крови больных РПЖ. Объект и методы исследования. Под наблюдением находились 195 мужчин с РПЖ в возрасте 52-82 лет. С момента диагностирования заболевания прошло в среднем 3 года. Соотношение рT2a, pT3a, pT3c, pPT4, pT2b, PT3, pT2c, pT3b, РТ2 стадий РПЖ было 1:1:1:2:3:5:7:7:9. Показатели pN1, pN2 и pN3 выявлены у 22, 9 и $8 \%$ обследованных соответственно, РМ1 и РМ2 - у 26 и $17 \%$ соответственно. Параметры распространенности рака в среднем составляли 3 балла, размера опухоли -2 балла, критерия Глисона -6 баллов, соотношение периферической и центральной формы опухоли $-3: 1$, аденокарциному диагностировали у $94 \%$ пациентов, гигантоклеточную карциному - у 6\%. Средний показатель стадии опухоли составлял 3 условные единицы, зрелости 3 балла. Оценивали показатели тестостерона, лютеинизирующего гормона, инсулиноподобного фактора роста 1 , активности щелочной фосфатазы, кислой простатической фосфатазы и гликозил-гидролазы. Результаты. Повышение уровня простатического специфического антигена, тестостерона, инсулиноподобного фактора роста 1 , активности щелочной фосфатазы, кислой простатической фосфатазы и козилгидролазы наблюдается у 46-100\% больных, зависит от распространенности, размеров, локализации, стадии и степени дифференциации опухолевого процесса, характера его метастазирования в лимфатические узлы, отдаленные органы и скелет, а параметры активности щелочной фосфатазы и кислой простатической фосфатазы имеют прогностическое значение. С учетом проделанной статистической обработки данных обследования сделан вывод, имеющий практическую направленность: показатель активности кислой простатической фосфатазы > 7,5 нг/мл имеет отрицательное прогностическое значение для метастазов в печень. Таким образом, необходима разработка новых алгоритмов, улучшающих дооперационную оценку стадий РПЖ. Вывод. Повышение уровня изученных маркеров РПЖ зависит от характера течения опухолевого процесса, а некоторые параметры имеют прогностическое значение.

Ключевые слова: рак; предстательная железа; опухолевые маркеры.
Significance of individual markers in different variants of prostate cancer

O.Yu. Stoliarova ${ }^{1}$, Yu.V. Dumanskiy ${ }^{2}$, M.I. Paliy ${ }^{1}$, O.V. Syniachenko ${ }^{3}$, M.V. Iermolaieva ${ }^{3}$

${ }^{1}$ National Cancer Institute, Kyiv ${ }^{2}$ RE Kavetsky Institute of Experimental Pathology, Oncology and Radiobiology, NAS of Ukraine, Kyiv ${ }^{3}$ Donetsk National Medical University, Lyman

Relevance. Prostate cancer (PC) is ranked first in the structure of oncological pathology in men, while it is the second most frequent cause of death from malignant neoplasms, and the five-year survival rate is $30 \%$. Prostate specific antigen is one of the main tumorassociated markers, and in certain variants of the course of prostate cancer, the diagnostic and prognostic significance of other markers remains poorly understood, although there are highly significant correlations between individual parameters in the blood. Objective of the study. To assess the clinical and prognostic significance of certain tumor markers in the blood of patients with prostate cancer. Study object and methods. The study included 195 men with prostate cancer aged 52 to 82 years. The duration from the moment of diagnosis of the disease was 3 years on average. The ratio pT2a, pT3a, pT3c, pT4, pT2b, pT3, pT2c, pT3b, pT2 of the prostate cancer stages was 1: 1: 1:2: 3: 5: 7: 7:9. The indices $\mathrm{pN} 1, \mathrm{pN} 2$ and $\mathrm{pN} 3$ were found, respectively, in $22 \%, 9 \%$ and $8 \%$ of the examined individuals, pM1 and pM2 in $26 \%$ and $17 \%$ of them. The parameters of cancer expansion were 3 points on average, tumor size -2 points, Gleason score -6 points, the ratio of peripheral to central tumor form was $3: 1$; adenocarcinoma was diagnosed in $94 \%$ of the cases, and giant cell carcinoma - in $6 \%$. The average tumor stage parameter was 3 relative units, maturity was 3 points. Blood levels of testosterone, luteinizing hormone, insulinlike growth factor 1, alkaline phosphatase, acid prostatic phosphatase and glycosyl hydrolase activities were evaluated. Results. An increase in the levels of prostate specific antigen, testosterone, insulin-like growth factor 1, alkaline phosphatase, acid prostatic phosphatase and glycosyl hydrolase is observed in $46 \%-100 \%$ of the patients, which depends on the expansion, size, localization, stage and degree of differentiation of the tumor process, the nature of its metastasis to lymph nodes, distant organs and skeleton, and alkaline phosphatase and acid prostatic phosphatase activity parameters have prognostic value. Taking into account the performed statistical processing of the examination data, the following conclusion was made, which has a practical orientation: acid prostatic phosphatase activity parameter $>7.5 \mathrm{ng} / \mathrm{ml}$ is predictive negative for liver metastases. According to the data of tumor markers, it is necessary to develop new algorithms to improve the preoperative assessment of the staging of prostate cancer. Conclusion. An increase in the level of the studied prostate cancer markers depends on the nature of the course of the tumor process, and some parameters have prognostic significance.

Key words: cancer; prostate gland; tumor markers.

Адреса для листування

Столярова Оксана Юріївна

03022, Київ, вул. Ломоносова, 33/43,

Національний інститут раку

E-mail: korifei1985@gmail.com

Correspondence

Stoliarova Oksana

33/43 Lomonosova Str., Kyiv 03022

National Cancer Institute

E-mail: korifei1985@gmail.com 